\title{
EFFECT OF FOLIAR SPRAY TECHNIQUE FOR MACRO AND MICRONUTRIENTS ON GROWTH AND YIELD OF FABA BEAN PLANTS, GROWN ON NEWLY RECLAIMED SOILS
}

Mohamed, H. Rabie; Ahmed, A. Khalil and Salah, E.M. El-Sisi Soil, Water and Environment Research Institute, ARC, Egypt.

\section{ABSTRACT}

Two field trials were conducted on Sandy loam and calcareous soils at Agric. Res. Stations of Ismailia and Nubaria, during the growing season 2003/2004 to study the effect of spraying NPK with or without micronutrients on the growth, yield, yield components and seed protein percentage of faba bean crop.

Generally, foliar spray with $\mathrm{P}$ and/or $\mathrm{K}$ with or without micronutrients, increased dry matter production, nutrients uptake, seed yield and seed protein percentage. However, the maximum figures were obtained when the mixture of $2 \% \mathrm{~N}$ as urea $+2 \% \mathrm{P}$ as superphosphate $+1 \% \mathrm{~K}$ as potassium sulphate + chelate of $\mathrm{Fe}, \mathrm{Mn}$, and $\mathrm{Zn}$ was used, two times (after 50 and 70 days from sowing). Results, also showed that the response of faba bean, in general, varied according to the location, soil fertility, kind and rate of the added fertilizers.

Key words: $\mathrm{N}$ as urea, $\mathrm{P}$ as Superphosphate $\mathrm{K}$ as potassium sulphate, Chelate of $\mathrm{Fe}, \mathrm{Mn}$, and $\mathrm{Zn}$ and Foliar spray

\section{INTRODUCTION}

Desert soils, either sandy or calcareous soils, have some constraints e.g. low organic matter and low available nutrients contents. (El-Saadani et al., 1987 and Rabie et al., 1997). Fababean (Vicia faba L.) is very important leguminous crop cultivated in Egypt. Increasing the quantity of the yield and improving the seed quality could be attained by various factors including the proper fertilization managements.

Concerning faba bean fertilization, conflicting outlooks and conclusions were claimed by numbers of workers e.g. Behairy et al. ( 1988), Hamissa et al. (1988), Monged et al. ( 1992), Hussein et al.( 1993), and Rabie et al.( 1997).

The current work was an attempt to elucidate the response of faba bean to $\mathrm{P}$ and/or $\mathrm{K}$ with or without a mixture of urea plus micronutrients added as foliar spray, in newly reclaimed soils.

\section{MATERIALS AND METHODS}

Two field experiments were conducted on faba bean plants (Vicia faba L) grown on both sandy loam and calcareous soils at Agric. Res. Stations, of Ismailia and Noubaria, respectively, during the growing season of 2003/2004 to study effect of $\mathrm{P}$ and / or $\mathrm{K}$ with and without a mixture of urea plus some micronutrients, as a foliar spray, on the quantity and quality of faba bean seed yield.

Surface soil samples were taken from the two experimental fields under study, air dried and prepared for some physical and chemical analysis, by using

Fayoum J. Agric. Res. \& Dev., Vol.19, No.2, July, 2005 
Mohamed, H. Rabie et al.

the standard procedures, according to Klute, (1986) and Jackson (1973). The studied soil properties are listed in Table (1).

Table ( 1 ) Some physical and chemical analyses of the investigated soils

\begin{tabular}{|c|c|c|}
\hline \multirow{2}{*}{ Soil characteristics } & \multicolumn{2}{|c|}{ Soil samples } \\
\hline & Ismailia & Noubaria \\
\hline$\underline{\text { Chemical analysis }}$ & & \\
\hline $\mathrm{pH}(1: 25)$ & 7.9 & 8.3 \\
\hline ECe $\left(\mathrm{dS} . \mathrm{m}^{-1}\right)$ & 0.46 & 1.38 \\
\hline Calcium carbonate \% & 2.1 & 35.0 \\
\hline Available $\mathrm{N}\left(\mathrm{mg} \mathrm{kg}^{-1}\right) *$ & 68 & 18 \\
\hline Available $\mathrm{P}\left(\mathrm{mg} \mathrm{kg}^{-1}\right) * *$ & 14.4 & 9.2 \\
\hline Available $\mathrm{K}\left(\mathrm{mg} \mathrm{kg}^{-1}\right) * * *$ & 260 & 150 \\
\hline Available $\mathrm{Fe}\left(\mathrm{mg} \mathrm{kg}^{-1}\right) * * * *$ & 6.3 & 2.3 \\
\hline Available $\mathrm{Zn}\left(\mathrm{mg} \mathrm{kg}^{-1}\right) * * * *$ & 1.3 & 0.4 \\
\hline Available $\mathrm{Mn}\left(\mathrm{mg} \mathrm{kg}^{-1}\right) * * * *$ & 2.6 & 1.2 \\
\hline Mechanical analysis & & \\
\hline Coarse sand \% & 74.8 & 79.5 \\
\hline Silt\% & 13.1 & 12.0 \\
\hline Clay\% & 12.0 & 6.8 \\
\hline Texture class & Sandy loam & Loamy Sand \\
\hline
\end{tabular}

The field trials were designed, as randomized complete block with four replicates and the plot area was $7.2 \mathrm{~m}^{2}$. Faba bean seeds (Giza 716 and Giza Blanca in Ismailia and Noubaria soils, respectively) were planted in the fixed plots of each field experiment after treated with specific rhizobia. Basal doses of phosphorus and potassium were added to all plots before sowing in the form of superphosphate $\left(\begin{array}{llll}15 & \% & \mathrm{P}_{2} \mathrm{O}_{5}\end{array}\right)$ at the rate of $30 \mathrm{~kg} \mathrm{P}_{2} \mathrm{O}_{5} /$ fed and potassium sulphate $\left(48 \% \mathrm{~K}_{2} \mathrm{O}\right)$ at a rate of $24 \mathrm{~kg} / \mathrm{fed}$ in a respective order. While, stimulating dose of nitrogen was added after 15 days from sowing at a rate 33.5 $\mathrm{kg} \mathrm{N} / \mathrm{fed}$, in the form of ammonium nitrate $(33.5 \% \mathrm{~N})$. Moreover, the other local recommended cultural practices were successfully applied.

After 50 and 70_days from sowing the foliar spray treatments were comprised as follows:

1- Control treatment.

2-Urea $(\mathrm{U}, 2 \%)+$ micronutrient $(\mathrm{M})$ as chelate fertilizer containing nutrients of $\mathrm{Fe}, \mathrm{Mn}$ and $\mathrm{Zn}(\mathrm{UM})$

3- Superphosphate ( $\left.\mathrm{SP}, 2 \% \mathrm{P}_{2} \mathrm{O}_{5}\right)$. 4- Potassium sulphate $\left(\mathrm{KS}, 1 \% \mathrm{k}_{2} \mathrm{O}\right)$.

$5-\mathrm{UM}+\mathrm{SP}$

6- UM + KS

7- SP+KS.

8- UM + SP + KS.

Fayoum J. Agric. Res. \& Dev., Vol.19, No.2, July, 2005 
EFFECT OF FOLIAR SPRAY TECHNIQUE FOR MACRO AND......... 205

Four plants were taken from each plot after 80 days from sowing; the plants were oven- dried at $70^{\circ} \mathrm{C}$, and dry matter of plants were recorded, The plant samples were ground for determining NPK uptake, according to Jackson (1973), While the micronutrient contents were estimated by the Atomic Absorption Spectrophotometer.

At harvesting, seeds yield for each plot was recorded, composite seed samples were taken, dried at $70^{\circ} \mathrm{C}$, fine-grounded and digested using concentrated sulphuric acid and hydrogen peroxide (FAO, 1980). Seed Nitrogen content was determined using the micro Kjeldahl technique (A.O.A.C. 1970) and seed protein content was calculated. Potassium and phosphorus contents were determined Flamphotometerically and Spectrophotometerically, in a respective order. $\mathrm{Fe}, \mathrm{Mn}$ and $\mathrm{Zn}$ were determined by the atomic Absorption Spectrophotometer.

The obtained results were statistically analyzed according to Snedecor and Cochran (1980).

\section{RESULTS AND DISCUSSION}

The effect of urea, $\mathrm{P}_{2} \mathrm{O}_{5}$ and $\mathrm{K}_{2} \mathrm{O}$, with and without micronutrients added as foliar spray on the dry weight production and nutrients uptake by faba bean plants grown on sandy loam and calcareous soils at Ismailia and Noubaria, respectively, are shown in Tables (2) and (3).

Results show that N, P and $\mathrm{K}$ with or without micronutrients significantly increased the dry weight production of fababean grown on a sandy loam soil at Ismailia, while the reverse was obtained when SP was used either alone or plus UM in the Noubaria calcareous soil, while the enhancing effects of other treatments were noticed. Hamisa et al., (1983) confirmed that these negative effects on the base of soil low fertility status, and applying foliar spray of certain nutrients increased the growth of faba bean. It is worthy to mention, that the positive effects are mainly due to the great necessity of these poor soils to nutrients addition.

In the sandy loam soils of Ismailia, data show that the positive effect of the above-mentioned treatments on dry weight production follows the order: (UM + $\mathrm{KS}+\mathrm{Sp})>(\mathrm{UM}+\mathrm{SP})>(\mathrm{SP})>(\mathrm{SP}+\mathrm{KS})>(\mathrm{UM}+\mathrm{KS})=\mathrm{KS}>\mathrm{UM}>$ control. While, in the calcareous soil, the effect of the used treatment could be arranged as follows: $(\mathrm{UM}+\mathrm{KS}+\mathrm{SP}) .>\mathrm{KS}>\mathrm{UM}>(\mathrm{SP}+\mathrm{KS})>(\mathrm{UM}+\mathrm{KS})>\mathrm{SP}=$ $(\mathrm{UM}+\mathrm{SP})=$ control.

Fayoum J. Agric. Res. \& Dev., Vol.19, No.2, July, 2005 
Mohamed, H. Rabie et al.

Table (2). Effect of spray treatments of urea, superphosphate and potassium sulfate with or without micronutrients on shoot dry weight of faba bean plant after 80 days from sowing, under sandy soil condition, at Ismailia Governorate.

\begin{tabular}{|c|c|c|c|c|c|c|c|c|c|}
\hline \multirow[b]{2}{*}{ No. } & \multirow[b]{2}{*}{ Treatments } & \multirow{2}{*}{$\begin{array}{l}\text { Shoots } \\
\text { dry wt. } \\
\text { (g/plant) }\end{array}$} & \multirow{2}{*}{$\begin{array}{c}\text { Dry wt. } \\
\text { Increasing } \\
\%\end{array}$} & \multicolumn{6}{|c|}{ Nutrients uptake ( mg/Plant) } \\
\hline & & & & $\mathbf{N}$ & $\mathbf{P}$ & $\mathbf{K}$ & $\mathbf{F e}$ & Mn & $\mathbf{Z n}$ \\
\hline 1 & Control & 12.5 & 0.0 & 153 & 15.2 & 146 & 4.30 & 0.50 & 1.25 \\
\hline 2 & UM & 13.3 & 6.4 & 301 & 16.5 & 112 & 5.63 & 0.73 & 1.64 \\
\hline 3 & $\mathrm{SP}$ & 14.4 & 15.2 & 201 & 25.2 & 181 & 5.20 & 0.54 & 1.41 \\
\hline 4 & KS & 13.7 & 9.6 & 256 & 17.9 & 222 & 5.86 & 0.75 & 1.47 \\
\hline 5 & $\mathrm{UM}+\mathrm{SP}$ & 14.8 & 18.4 & 261 & 31.7 & 95 & 6.81 & 0.89 & 2.21 \\
\hline 6 & $\mathrm{UM}+\mathrm{KS}$ & 13.7 & 9.6 & 270 & 19.7 & 194 & 5.80 & 0.71 & 1.63 \\
\hline 7 & $\mathrm{SP}+\mathrm{KS}$ & 14.0 & 12.0 & 247 & 26.4 & 241 & 6.87 & 0.62 & 1.53 \\
\hline \multirow[t]{2}{*}{8} & $\mathrm{UM}+\mathrm{SP}+\mathrm{KS}$ & 14.9 & $19 . .2$ & 309 & 33.9 & 258 & 7.21 & 0.91 & 2.26 \\
\hline & LSD (5\%) & 1.7 & $\ldots \ldots$ & 49.3 & 4.8 & 42.2 & 0.87 & 0.12 & 0.20 \\
\hline
\end{tabular}

Note: Control = water spray; $\mathbf{U M}=$ mixture of urea $2 \%+$ micronutrients chelates $(\mathrm{Fe}$. $\mathbf{M n}, \mathrm{Zn}) \mathbf{S P}=$ superphosphate; $\mathbf{K S}=$ potassium sulfate

Table (3). Effect of spray treatments of urea, superphosphate and potassium sulfate with or without micronutrients on shoot dry weight of faba bean plant after 80 days from sowing under calcareous soil condition at Noubarea.

\begin{tabular}{|c|c|c|c|c|c|c|c|c|c|}
\hline \multirow[b]{2}{*}{ No. } & \multirow[b]{2}{*}{ Treatments } & \multirow{2}{*}{$\begin{array}{l}\text { Shoots } \\
\text { dry wt. } \\
\text { (g/plant) }\end{array}$} & \multirow{2}{*}{$\begin{array}{c}\text { Dry wt. } \\
\text { Increasing } \\
\%\end{array}$} & \multicolumn{6}{|c|}{ Nutrients uptake (mg/Plant) } \\
\hline & & & & $\mathbf{N}$ & $\mathbf{P}$ & $\mathbf{K}$ & $\mathbf{F e}$ & Mn & Zn \\
\hline 1 & Control & 22.6 & 0.0 & 401 & 39.0 & 570 & 3.39 & 0.59 & 2.14 \\
\hline 2 & UM & 24.5 & 8.4 & 482 & 46.8 & 647 & 5.15 & 0.79 & 2.28 \\
\hline 3 & SP & 22.6 & 0.0 & 491 & 53.3 & 580 & 3.93 & 0.74 & 2.16 \\
\hline 4 & $\mathrm{KS}$ & 24.7 & 9.2 & 516 & 49.5 & 871 & 5.55 & 1.12 & 2.25 \\
\hline 5 & $\mathrm{UM}+\mathrm{SP}$ & 22.6 & 0.0 & 474 & 45.8 & 677 & 4.64 & 1.05 & 2.22 \\
\hline 6 & $\mathrm{UM}+\mathrm{KS}$ & 23.0 & 1,7 & 504 & 45.8 & 795 & 6.10 & 1.48 & 2.37 \\
\hline 7 & $\mathrm{SP}+\mathrm{KS}$ & 23.6 & 4.4 & 551 & 47.3 & 903 & 9.14 & 0.94 & 2.17 \\
\hline 8 & $\mathrm{UM}+\mathrm{SP}+\mathrm{KS}$ & 24.7 & 9.3 & 594 & 49.5 & 1132 & 9.34 & 1.60 & 2.39 \\
\hline & LSD $(5 \%)$ & 2.3 & ----- & 66.5 & 6.5 & 108 & 0.75 & 0.45 & $\begin{array}{ll}---- \\
\end{array}$ \\
\hline
\end{tabular}

Note: Control $=$ water spray; $\mathbf{U M}=$ mixture of urea $2 \%+$ micronutrients chelates (Fe. $\mathrm{Mn}, \mathrm{Zn}) \quad \mathbf{S P}=$ superphosphate; $\mathbf{K S}=$ potassium sulfate

Concerning the nutrients uptake by Faba bean (N,P,K,Fe,Mn,and $\mathrm{Zn}$ as $\mathrm{mg} /$ plant),data in tables $(2,3)$ show significant values for all applied treatments. It's noticed that the treatments including urea achieved the relatively higher values than the others, the highest nutrient contents uptake were observed in treatment No. 8, in which a mixture of urea + micronutrients was mixed with

Fayoum J. Agric. Res. \& Dev., Vol.19, No.2, July, 2005 
EFFECT OF FOLIAR SPRAY TECHNIQUE FOR MACRO AND......... 207 both superphosphate and potassium sulphate solutions, in both soils under investigation, except of Pin the calcareous soil which reached the maximum level at SP treatment Many workers, on faba bean reached partial similar results, e.g. added as foliar spray Hamissa et al. (1988), Amin et al. (1988) and Rabie et al. (1997).

In general, $\mathrm{N}, \mathrm{P}$, and $\mathrm{K}$ uptake by faba bean plants ( 80 days age), reveal that their values significantly increased by the foliar spray addition of whichever.

The data illustrated in the above mentioned Tables also, show significant effects of all treatments under study on $\mathrm{Fe}, \mathrm{Mn}$ and $\mathrm{Zn}$ uptake by faba bean plants. Agron the treatment No. 8 were the superior one, compared with other treatments, in either sandy loam or calcareous soils. However, the highest nutrients uptake was found under calcareous soil conditions. The last result is mainly due to high dry weight of faba bean (Giza Blanca cv), which grown on that soil. Monged et al. (1992) conducted field experiments on faba bean under four governorates conditions, and found that the response of micronutrients addition, in general, varied according to soil type, the used element and its source.

Whether or not, on both sandy loam and calcareous soils, the highest magnitude of average dry matter accumulation and nutrients uptake, either macro- or micronutrients, can be achieved by treating faba bean plants by a mixture of $2 \%$ urea + micronutrients + superphosphate $(2 \%)+$ potassium sulfate $(1 \%)$, two times (after 50 and 70 days from sowing). The beneficial effects of micronutrients could be referred to the influence on selection transfer reaction including those in the Kreb's cycle and subsequently on energy production in the plants (Hussein et al., 1993 and Rabie et al, 1997).

Data concerning faba bean seed yield, yield components and seed protein content in sandy loam and calcareous soils under investigation are illustrated in Tables (4 and 5), respectively. These data show that when faba bean plants were treated only with superphosphate or potassium sulfate, the number of pods were increased by 7.7 and $8.8 \%$ over the treatment control in sandy loam soil and uptake about $8.4 \%$ over the control in calcareous soil. Similar percentage increases were found in both studied soils when treated a mixture of urea plus micronutrients .

The number of seeds per plant were paralleled to the aforesaid results in both soils under study. It was noticed, that treatments Nos. 5,6 and 8 produced a significant increases in seed yield in sandy loam and calcareous soils, as compared with the control treatment, However, the highest seed yield was obtained by spraying a mixture of urea + micronutrients + superphosphate + potassium sulfate, two times (after 50 and 70 days from sowing), specially under sandy loam soil condition of Ismailia.

In spite of, the high dry matter, production and consequently the high nutrients uptake of faba bean plants grown on calcareous soil, at Nubaria, compared with those grown on sandy loam soil at Ismailia, lower faba bean seed yield and its components were obtained in calcareous soil than sandy loam soil (Tables, 4 and 5). These conflicting results may be due to the differences in plants genetically characteristics and the low fertility that is affected by the occurrence of $\mathrm{CaCo}_{3}$ which restrict the availability of nutrient, and in tarn seed

Fayoum J. Agric. Res. \& Dev., Vol.19, No.2, July, 2005 
Mohamed, H. Rabie et al.

yield and its protein content.

The effect of the applied treatments on seed yield could be arranged as follows: treatment No. $8>7=6>5>4=3>2$ in the sandy loam soil, the corresponding categories in the calcareous soil they were as follows: treat. No.8> $5>7=6>3>4>2$.

Table (4). Effect of added as foliar spray urea, superphosphate and potassium sulfate with or without micronutrients on yield, yield components and seeds protein content of faba bean grown on Ismailia .sandy loam soil

\begin{tabular}{|c|c|c|c|c|c|c|c|c|c|}
\hline No. & Treatments & $\begin{array}{c}\text { Pods } \\
\text { No./ } \\
\text { plant }\end{array}$ & $\begin{array}{c}\text { Increasing } \\
\text { rate \% }\end{array}$ & $\begin{array}{c}\text { Seeds } \\
\text { No./ } \\
\text { Plant }\end{array}$ & $\begin{array}{c}\text { Increasing } \\
\text { rate } \\
\%\end{array}$ & $\begin{array}{c}\text { Seed } \\
\text { yield } \\
\text { (ton/fed) }\end{array}$ & $\begin{array}{c}\text { Increasing } \\
\text { rate } \\
\%\end{array}$ & $\begin{array}{c}\text { Seeds } \\
\text { protein } \\
\text { Content } \\
\%\end{array}$ & $\begin{array}{c}\text { Increasing } \\
\text { rate } \\
\%\end{array}$ \\
\hline 1 & Control & 17.0 & ----- & 40.8 & ----- & 1.37 & ---- & 28.3 & ---- \\
\hline 2 & UM & 18.5 & 8.8 & 43.5 & 6.2 & 1.38 & 0.7 & 29.0 & 2.5 \\
\hline 3 & SP & 18.3 & 7.7 & 44.5 & 9.1 & 1.42 & 3.6 & 29.0 & 2.5 \\
\hline 4 & KS & 18.5 & 8.8 & 44.8 & 9.8 & 1.43 & 4.4 & 29.2 & 3.2 \\
\hline 5 & $\mathrm{M}+\mathrm{SP}$ & 20.5 & 20.5 & 53.8 & 31.9 & 1.48 & 15.3 & 30.1 & 6.4 \\
\hline 6 & $\mathrm{UM}+\mathrm{KS}$ & 21.5 & 26.5 & 54.5 & 25.1 & 1.62 & 18.3 & 32.2 & 13.8 \\
\hline 7 & $\mathrm{SP}+\mathrm{KS}$ & 22.8 & 34.1 & 58.3 & 42.9 & 1.63 & 18.9 & 29.4 & 3.9 \\
\hline 8 & $\mathrm{JM}+\mathrm{SP}+\mathrm{K}$ & 23.3 & 37.1 & 59.5 & 45.8 & 1.67 & 21.9 & 32.2 & 13.9 \\
\hline \multicolumn{2}{l}{ LSD $(5 \%)$} & 2.9 & --- & 7.9 & ----- & 0.14 & ---- & 0.98 & ---- \\
\hline
\end{tabular}

Table (5). Effect of added as foliar spray urea, superphosphate and potassium sulfate with or without micronutrients on yield, yield components and seeds protein content of faba bean grown on Nubaria, calcareaus soil.

\begin{tabular}{|c|c|c|c|c|c|c|c|c|c|}
\hline No. & Treatments & $\begin{array}{c}\text { Pods } \\
\text { No./ } \\
\text { plant }\end{array}$ & $\begin{array}{c}\text { Increasing } \\
\text { Rate } \\
\%\end{array}$ & $\begin{array}{c}\text { Seeds } \\
\text { No/plant }\end{array}$ & $\begin{array}{c}\text { Increasing } \\
\text { Rate } \\
\%\end{array}$ & $\begin{array}{c}\text { Seeds } \\
\text { yield } \\
\text { ton/fed) }\end{array}$ & $\begin{array}{c}\text { Increasing } \\
\text { rate } \\
\%\end{array}$ & $\begin{array}{c}\text { Seeds } \\
\text { protein } \\
\text { content } \\
\%\end{array}$ & $\begin{array}{c}\text { Increasing } \\
\text { Rate } \\
\%\end{array}$ \\
\hline 1 & Control & 8.3 & --- & 37.8 & --- & 0.99 & --- & 17.5 & --- \\
\hline 2 & UM & 9.0 & 8.4 & 40.4 & 6.9 & 1.05 & 6.0 & 18.0 & 2.9 \\
\hline 3 & SP & 9.0 & 8.4 & 38.3 & 2.7 & 1.08 & 9.0 & 19.2 & 9.8 \\
\hline 4 & KS & 9.0 & 8.4 & 38.2 & 1.1 & 1.06 & 7.1 & 19.1 & 9.1 \\
\hline 5 & UM+ SP & 12.8 & 54.2 & 44 & 17.5 & 1.24 & 25.3 & 19.3 & 10.3 \\
\hline 6 & UM+ KS & 12.5 & 50.6 & 48.4 & 28.0 & 1.22 & 23.2 & 19.7 & 12.6 \\
\hline 7 & SP + KS & 11.6 & 39.8 & 45.3 & 19.8 & 1.22 & 23.2 & 19.2 & 9.8 \\
\hline 8 & UM+SP+KS & 13.3 & 60.2 & 53.0 & 40.2 & 1.32 & 38.4 & 20.0 & 14.3 \\
\hline & LSD $(5 \%)$ & 0.8 & ---- & 2.9 & --- & 0.21 & --- & 1.7 & --- \\
\hline
\end{tabular}

Tables (4 and 5) also, show that all treatments using spraying $\mathrm{P}, \mathrm{K}$ with or without micronutrients, show significant increases in seed protein content in both studied soils. Thereby, in sandy loam soil, faba been protein content achieved an increase of 13.9 and $13.8 \%$, over the control for treatments No. 8 and 6 , respectively. While in the calcareous soil, the seed protein increased by

Fayoum J. Agric. Res. \& Dev., Vol.19, No.2, July, 2005 
EFFECT OF FOLIAR SPRAY TECHNIQUE FOR MACRO AND......... 209 14.3 and $12.6 \%$ in the same treatments mentioned before.

Finally, the maximum dry weight production, nutrients uptake, seed yield and seeds protein percentage were obtained, when the spraying treatment include mixture of urea $(2 \%)+$ chelate micronutrients, $(\mathrm{Fe}, \mathrm{Mn}$ and $\mathrm{Zn})+$ superphosphate $(2 \%)+$ potassium sulfate $(1 \%)$, in both sandy loam and calcareous soils. These results are partially in agreement with those obtained by Rabie et al. (1997). Moreover, results show that the response of faba bean, in general, varied according to status soil types, soil fertility and the rates of the applied nutrients. Monged et al. (1992) obtained similar results.

\section{REFERENCES}

A.O.A.C. (1970). Official Methods of Analysis $11^{\text {th }}$ ed. Association of Official Agricultural Chemists. Washington, D.C., USA.

Amin, M.A.A ; M.S.M., Baza and F.H. Elgendy (1988). Effect of numbers of sprays of some micronutrients on the growth, yield and mineral composition of faba bean plant. Annals of Agric. Sci. Moshtohor, Vol. 26 No. 6, Zag. Univ.

Bihairy, T.G. ; A.O.M. Saad and M.O. Kabesh (1988). Increasing broad bean yield by early and late nitrogen fertilization. Egypt J. Agron. 13 (1): $145-147$.

Klute, A. (ed.) (1986), Methods of Soil Analysis. Part-1: Physical and Minerological Methods. (2 ${ }^{\text {nd }}$ ed.) American Society of Agronomy. Madison, Wisconson, USA.

El-Saadani, AM. ; M.H. Rabie; E.A Abdellatif and A.H. Abdel Hadi (1987). Status of chemical available nutrients in some cultivated sandy soils of Ismailia govemorate. Proceeding of the $1^{\text {st }}$ Conf. of Fertilizers Availability and Needs. April 13-16, 1987 Cairo, Egypt.

FAO (1980). Soil and plant analysis as a basis of fertilizer recommendations. Soils Bulletin No. 38 (2): FAO, Roma.

Hamissa M.R. (1983). Fertility studies on faba bean in the Nile Valley. Report on the $1^{\text {st }}$ phase of ICARDA/IFAD Nile Valley Project.

Hamissa M.R.; M. Taha; M.S. Khader and M.L. EI-Mallah (1988). Crop yield of fababean and amount of fixable - $\mathrm{N}$ as affected by foliar spray using tracer technique. Agric. Res. Review, 66 (4): 707-723.

Hussein, A.H.A.; W. Kadry, R.F. Dessouky; A.M. Hassanein and M.A. ElDeeb. (1993). Effect of different levels and application method of phosphorus and some micronutrients on disease severity of chocolate spot and rust, yield and yield components of faba bean in calcareous soil. Egyptian J. Appli. Sci. Zagazig Univ. 8 (7): 387-397.

Jackson, M.L. (1973). Soil Chemical Analysis. Prentice Hall of India, Private Limited, New Delhi., India.

Lindsay, W.L. and W.A Norvell (1978). Development of DTPA soil tests for $\mathrm{Zn}, \mathrm{Fe}, \mathrm{Mn}$ and Cu. Soil Sci. Soc. Am. J., 42: 421-428.

Monged, M.O.; M.S.M. Bazza and T.A. Abo-Eldefan (1992). Effect of some micronutrients, on faba bean yield under four governorates in A.R. Egypt. J. Appl. Sci., 7 (4): 597- 601.

Fayoum J. Agric. Res. \& Dev., Vol.19, No.2, July, 2005 
Mohamed, H. Rabie et al.

Olsen, S.; E.A. Cole and F.S. Watanabe (1954). Estimation of available phosphorus in soils by extraction with sodium bicarbonate. USDA, Circular No. 939.

Rabie, M.H.; M.S. Said; A.M. Awad and M.E. Khalil (1997). Effect of foliar application of urea and micronutrient on seed quality of fababean and lentil under calcareous soil conditions. J. Agric. Sci. Mansoura Univ., 24 (10): 6217 - 6224.

Snedecor,Ga.W. and Cochran, W.G. (1980)."Statistical Methods."7"th: Ed.The Lowa State Univ. Press, Amer. Lowa, U.S.A.

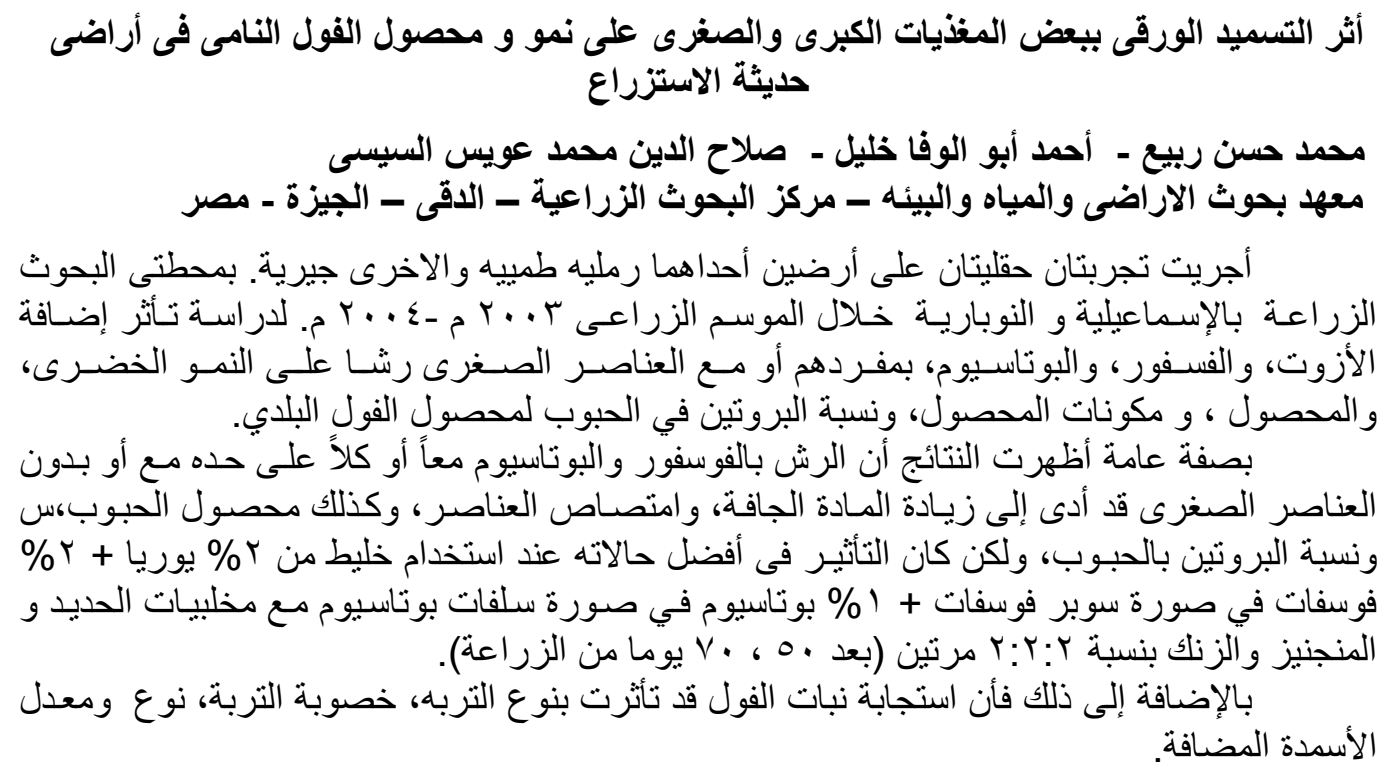

Fayoum J. Agric. Res. \& Dev., Vol.19, No.2, July, 2005 